\title{
КОНТРОЛЬ ВТОРИННОГО ГІПЕРПАРАТИРЕОЗУ ВНУТРІШНЬОВЕННИМ ВВЕДЕННЯМ ПРЕПАРАТУ ПАРСАБІВ У ХВОРИХ НА ХРОНІЧНУ ХВОРОБУ НИРОК УД СТАДІЇ, ЯКІ ЛІКУЮТЬСЯ ГЕМОДІАЛІЗОМ В ПОРІВНЯННІ З ЦИНАКАЛЬЦЕТОМ
}

\author{
КРАСЮК Е.К., ГРИГОР'ЄВА Є.М., СЕМЕРИК Ю.П. \\ Комунальне неприбуткове підприємство \\ “Київський міський центр нефрології та діалізу” \\ Київ, Україна
}

Резюме

Ключові слова:

Вступ. Вторинний гіперпаратиреоз (ВГПТ), часте ускладнення хронічного захворювання нирок, яке характеризується підвищеним вмістом паратиреоїдного гормону (ПТГ) в сироватці крові. Парсабів (етелкальцетид) $€$ кальциміметиком для внутрішньовенного введення, який підвищує чутливість кальцій-чутливого рецептора до кальцію та знижує секрецію ПТГ.

Мета. Оцінка контролю ВГПТ внутрішньовенним введенням препарату Парсабів у хворих з термінальною хронічною хворобою нирок $(\mathrm{XXH})$, які лікуються методом гемодіалізу (ГД) в порівнянні з цинакальцетом для перорального прийому.

Матеріали та методи. Проведене проспективне обсерваційне дослідження з включенням 40 пацієнтів з ВГПТ, що лікуються методом ГД, які раніше не отримували відповідного лікування (тобто, ніколи раніше не отримували кальциміметики), пацієнтам, які раніше отримували цинакальцет, а також пацієнти, які продовжили отримувати цинакальцет. Первинним кінцевим критерієм ефективності була кількість пацієнтів зі зниженням вмісту ПТГ на понад 30\%, в порівнянні із показниками на початку лікування, на етапі оцінки ефективності (тижні 12-14) та оцінка того, чи забезпечує Парсабів ефективніший за цинакальцет контроль ВГПТ. Вторинні кінцеві критерії були представлені часткою пацієнтів, які досягли протягом періоду оцінки ефективності зниження концентрації ПТГ на понад 50\% у порівнянні з вихідним рівнем та відсоткове зниження вмісту ПТГ та кальцію.

Результати та їх обговорення. В дослідження були включені дані 40 пацієнтів, отримані за період спостереження тривалістю 14 тижнів. Середній вік 40 пацієнтів становив 47,62 $\pm 12,97$ роки, 70\% були чоловіками. Середня тривалість проведення діалізу становила 8,3 $\pm 2,34$ років. Середня концентрація ПТГ до початку дослідження та протягом 12-14 тижнів становила 1137,34 $\pm 544,84$ та 838,7 \pm 458,8 пг/ мл і 1010,6 \pm 478,53 та 760,8 \pm 373,86 пг/мл в групах Парсабіву та цинакальцету, відповідно. Середній вміст загального кальцію залишився в межах діапазону норми у групі Парсабіву та у групі цинакальцету, хоча зниження рівня загального кальцію і був більшим в групі Парсабіву (2,23\% в порівнянні з 5,15\%), в усіх випадках це не супроводжувалась симптомами.

Висновки. Результати проведеного нами обсерваційного дослідження представляють клінічний інтерес. Вони підтверджують, що застосування Парсабіву $є$ новим важливим варіантом лікування пацієнтів з ВГПТ. Парсабів виявив більшу ефективність контролю ВГПТ у пацієнтів в порівнянні із застосуванням цинакальцету. На додаток, застосування Парсабіву сприяє зниженню навантаження, спричиненого необхідністю прийому великої кількості лікарських засобів, характерне для пацієнтів на діалізі, i, таким чином, може сприяти кращому дотриманню рекомендованого терапевтичного режиму, та усуненню ризику стійкого ВГПТ. Також є важливим, що Парсабів не взаємодіє з ізоферментами системи цитохрому Р450, тобто, відсутні взаємодії з іншими лікарськими засобами, які отримують пацієнти на діалізі.

Необхідне проведення подальших досліджень для оцінки клінічних наслідків, а також ефективності та безпеки при довготривалому застосуванні.

хронічна хвороба нирок, гемодіаліз, етелкальцетид, Парсабів, цинакальцет, вторинний гіперпаратиреоз. 
Вступ. Поширеність і захворюваність на XXH $\epsilon$ важливою проблемою охорони здоров'я як в Україні, так і в усьому світі. Прогресуючий перебіг XXH супроводжується розвитком термінальної (V стадії) хвороби, яка потребує лікування методами ниркової замісної терапії (НЗТ) [1]. Вторинний гіперпаратиреоз $€$ серйозним ускладненням XXH, зокрема, у пацієнтів, яким потрібний діаліз. Збільшена концентрація ПТГ в сироватці крові сприяє розвитку порушень 3 боку кісткових тканин та серцево-судинних захворювань (включно з фіброзною генералізованою остеодистрофією та серцево-судинними порушеннями внаслідок кальцифікації, які мають спільну назву XXH опосередковане порушення мінералізації кісткової тканини), а також міопатії, нейропатії, анемії та свербожу, має незалежний зв'язок з підвищенням смертності незалежно від причин та смертності внаслідок серцево-судинних порушень. Відомо, що при рівні ПТГ вище 600 пг/мл ризик смерті збільшується в 2 рази за рахунок судинної кальцифікації, кальцинозу клапанів, ішемічної хвороби серця, цереброваскулярних захворювань, гіпертензії [2]. Поточні варіанти лікування полягають в застосуванні препаратів для перорального прийому, зв'язувачів фосфатів в кишечнику, перорального або внутрішньовенного введення кальцитріолу або аналогів активного вітаміну $\mathrm{D}$, а також кальциміметика для перорального застосування, цинакальцету. Ці втручання часто обмежені небажаними побічними реакціями чи небажаними явищами, деякі 3 них вимагають дотримання рекомендованого режиму щоденного прийому або прийому тричі на добу [3].

Застосування цинакальцету для перорального прийому обмежене недотриманням рекомендованого терапевтичного режиму. Цинакальцет для перорального прийому був єдиним доступним кальциміметиком аж до нещодавнього схвалення кальциміметика для в/в введення, етелкальцетиду (Парсабів).

Етелкальцетид, призначений для внутрішньовенного введення 8-амінокислотного алостерного активатора кальційчутливого рецептора (CaSR), збільшує чутливість рецептора до Са, завдяки чому знижується секреція ПТГ та знижується вміст ПТГ в циркулюючій крові. Безпека та ефективність етелкальцетиду, при введенні тричі на тиждень, на завершенні кожного сеансу гемодіалізу, неодноразово були продемонстровані в дослідженнях [5].

Проведене дослідження демонструє ефективність застосування Парсабіву у зв'язку 3 ВГПТ у пацієнтів на гемодіалізі в порівнянні з цинакальцетом.

Мета. Оцінити контроль ВГПТ шляхом внутрішньовенного введення препарату Парсабів у хворих XXН VД стадії, які лікуються методом ГД в порівнянні з цинакальцетом для перорального прийому.

Матеріали і методи. Проведене проспективне обсерваційне дослідження з включенням 40 хворих з діагнозом XXН VД стадії з ВГПТ, які перебувають на амбулаторному лікуванні сеансами ГД у КНП «Київський міський центр нефрології та діалізу». 3 них 15 (37,5\%) пацієнтів отримували цинакальцет, а $25(62,5 \%)$ пацієнтів отримували Парсабів. Частина пацієнтів раніше не отримували відповідного лікування (тобто, ніколи раніше не отримували кальциміметики), а частина отримували Парсабів, як замінник цинакальцету, причина переведення пацієнтів на Парсабів полягала в сподіванні на забезпечення кращого контролю вмісту ПТГ в сироватці крові, зниження частоти побічних явищ, а також покращення дотримання пацієнтами терапевтичного режиму завдяки зменшенню кількості лікарських препаратів, які їм слід приймати [6]. Середній вік 40 пацієнтів становив 47,62 $\pm 12,97$ роки, $51,28 \pm 10,88$ роки у групі пацієнтів, які отримували Парсабів і $41,63 \pm 14,26$ роки у групі пацієнтів, які отримували цинакальцет. Ними були, переважно, чоловіки 70\%, 64\% чоловіків у групі пацієнтів, які отримували Парсабів і $80 \%$ у групі пацієнтів, які отримували цинакальцет). Середня тривалість перебування на ГД серед 40 пацієнтів становила 8,3 $\pm 2,34$ років, 5,69 \pm 2,22 роки у групі пацієнтів, які отримували Парсабів і $12,67 \pm 4,99$ роки у групі пацієнтів, які отримували цинакальцет. Причиною, захворюванням нирок, був хронічний гломерулонефрит у вісімнадцяти пацієнтів, діабетична нефропатія у чотирьох, нефроангіосклероз в одного, полікістоз нирок у семи, системні захворювання у двох, урологічні хвороби у трьох та вроджені або спадкові захворювання у п'яти.

Лабораторне обстеження проводилось в лабораторії КНП "Київського міського центру нефрології та діалізу”. Тривалість інтервалу між обстеженнями визначав кожний лікуючий лікар індивідуально. Зразки для біохімічного аналізу отримували до початку сеансу гемодіалізу до початку лікування та періодично (в середньому 1 раз на місяць) протягом 14 тижнів. Здійснювали мультибіохімічний аналіз крові та визначення рівня загального кальцію, фосфору та ПТГ.

3 урахуванням результатів аналізів та клінічного досвіду лікуючі лікарі змінювали дозу Парсабіву (від 2,5 мг до 15 мг, тричі на тиждень, 3 кроком 2,5 мг або 5 мг, відповідно до рекомендацій компанії-виробника), також лікарі мали можливість, при необхідності, коригувати дозу зв'язувачів фосфатів, стеролів вітаміну D, харчових додатків кальцію, а також концентрацію кальцію в діалізаті. 
Початкова доза Парсабіву становила 2,5 мг/ сеанс для пацієнтів, які раніше отримували цинакальцет дозою 30 мг/добу, та 5 мг/сеанс для пацієнтів, які раніше отримували цинакальцет дозою 60 або 90 мг/добу, надалі, в період спостереження після переведення, дозу коригували з урахуванням результатів клінічного моніторингу та аналізів крові, максимальна доза повинна була не перевищувати 15 мг/сеанс. Тривалість періоду для виведення раніше отримуваного препарату, при переведенні, становила один тиждень.

Первинним кінцевим критерієм ефективності була кількість пацієнтів зі зниженням вмісту ПТГ на понад $30 \%$, в порівнянні із показниками на початку лікування, на етапі оцінки ефективності (тижні 12-14). Вторинні кінцеві критерії були представлені часткою пацієнтів, які досягли протягом періоду оцінки ефективності зниження концентрації ПТГ на понад $50 \%$ у порівнянні 3 вихідним рівнем та відсоткове зниження вмісту ПТГ та кальцію.

Наше відділення діалізу дотримується рекомендацій, наведених в клінічних настановаx KDIGO $[20,21]$. Для пацієнтів на ГД діапазон вмісту ПТГ, рекомендований настановами KDIGO, перевищує у 2-9 разів верхню межу норми. За відсутністю точнішої інформації настановою рекомендовано здійснювати оцінку тенденцій та уникати значень менше за 100 та вище за 500 пг/мл [7, 8].

При проведенні аналізу методами описової статистики, дані були підсумовані, як середні \pm стандартне відхилення (СВ), або як відсоток від частоти, в залежності від ситуації. Достовірний рівень $\mathrm{p}<0,05$ був класифікований, як достовірний. Статистичний аналіз результатів дослідження проводився за допомогою програми STATISTICA для Windows, версія 10.

Результати та їх обговорення. У дослідження було включено 40 пацієнтів, з них 15 (37,5\%) пацієнтів отримували цинакальцет, а 25 (62,5\%) пацієнтів отримували Парсабів. Демографічні та клінічні характеристики пацієнтів до початку дослідження наведені в Таблиці 1. Середній вік 40 пацієнтів становив 47,62 $\pm 12,97$ роки, $51,28 \pm 10,88$ роки у групі пацієнтів, які отримували Парсабів і $41,63 \pm 14,26$ роки у групі пацієнтів, які отримували цинакальцет. Ними були, переважно, чоловіки 70\%, 64\% чоловіків у групі пацієнтів, які отримували Парсабів і $80 \%$ у групі пацієнтів, які отримували цинакальцет. Середня тривалість перебування на ГД серед 40 пацієнтів становила $8,3 \pm 2,34$ років, $5,69 \pm 2,22$ роки у групі пацієнтів, які отримували Парсабів і $12,67 \pm 4,99$ роки у групі пацієнтів, які отримували цинакальцет. Причиною захворюванням нирок був хронічний гломерулонефрит у вісімнацяти пацієнтів, діабетична нефропатія у чотирьох, нефроангіосклероз у одного, полікістоз нирок у семи, системні захворювання у двох, урологічні хвороби у трьох та вроджені або спадкові захворювання у п'ятьох. Всі 40 пацієнтів отримували 4-годинні сеанси ГД тричі на тиждень.

Таблиця 1

Клініко-демографічна характеристика пацієнтів до початку дослідження

\begin{tabular}{|l|c|c|}
\hline \multicolumn{1}{|c|}{ Характеристика } & $\begin{array}{c}\text { Пацієнти, які отримували } \\
\text { Парсабів }\end{array}$ & $\begin{array}{c}\text { Пацієнти, які отримували } \\
\text { цинакальцет }\end{array}$ \\
\hline Стать ч, абс., (\%) & $16(64)$ & $12(80)$ \\
\hline Вік, роки & $51,28 \pm 10,88$ & $41,63 \pm 14,26$ \\
\hline Тривалість лікування ГД, роки & $5,69 \pm 2,22$ & $12,67 \pm 4,99$ \\
\hline Результати лабораторних аналізів, середні значення (СВ) \\
\hline ПТГ, пг/мл & $1137,34 \pm 544,84$ & $1010,6 \pm 478,53$ \\
\hline Са, ммоль/л & $2,31 \pm 0,61$ & $2,25 \pm 0,23$ \\
\hline
\end{tabular}

На початку дослідження середня доза цинакальцету становила $53,6 \pm 18,83$ мг. Початкова доза етелкальцетиду становила 4,35 $\pm 1,39$ мг/сеанс (по 2,5 мг для пацієнтів, що приймали цинакальцет дозою 30 мг/добу, та по 5 мг/сеанс для пацієнтів, що приймали цинакальцет дозою 60 або 90 мг/добу, або яким вперше розпочато лікування кальциміметиком). В процесі лікування, враховуючи зміну вмісту ПТГ протягом дослідження дозу Парсабіву було скориговано до 4,79 $\pm 1,43$, цинакальцету $-51,0 \pm 32,62$ мг.
Первинним кінцевим критерієм ефективності була кількість пацієнтів зі зниженням вмісту ПТГ на понад $30 \%$, в порівнянні із показниками на початку лікування, на етапі оцінки ефективності. Для пацієнтів з групи отримання Парсабіву ймовірність досягнення первинної кінцевої точки ефективності була вірогідно більшою, ніж для пацієнтів з групи отримання цинакальцету: 13/25 (52\%) пацієнтів в порівнянні із 6/15 (40\%).

Вторинними кінцевими критеріями були частка пацієнтів, які досягли зниження концен- 
трації ПТГ на більше $50 \%$ у порівнянні з вихідним рівнем, відсоткове зниження вмісту ПТГ та кальцію. Частка пацієнтів, які досягли протягом періоду оцінки ефективності зниження концентрації ПТГ на більше $50 \%$ у групі Парсабіву становить $20 \%$ у порівнянні $313,3 \%$ у групі цинакальцету. Середня концентрація ПТГ до початку дослідження та протягом 12-14 тижнів у групі Парсабіву становила $1137,34 \pm 544,84$ та 838,7 $\pm 458,8$ пг/мл, що відповідає зниженню рівня ПТГ на 26,26\%; у групі цинакальцету відповідно
$1010,6 \pm 478,53$ та 760,8 \pm 373,86 пг/мл, що відповідає зниженню рівня ПТГ на 24,72\%. Середній вміст загального кальцію залишився в межaх діапазону норми у групі Парсабіву та у групі Цинакальцету, хоча зниження рівня загального кальцію і був більшим в групі Парсабіву $(2,23 \%$ в порівнянні з 5,15\%), в усіх випадках це не супроводжувалась симптомами. Результати введення препарату Парсабів хворим з ХХН, які лікуються ГД в порівнянні з прийомом цинакальцету наведені в таблиці 2.

\section{Результати введення препарату Парсабів хворим з XXН, які лікуються ГД В порівнянні з прийомом цинакальцету}

\begin{tabular}{|l|c|c|}
\hline \multicolumn{1}{|c|}{$\begin{array}{c}\text { Параметри оцінки } \\
\text { ефективності }\end{array}$} & $\begin{array}{c}\text { Група хворих, які отримували } \\
\text { Парсабів }\end{array}$ & $\begin{array}{c}\text { Група хворих, які отримували } \\
\text { цинакальцет }\end{array}$ \\
\hline $\begin{array}{l}\text { Зниження вмісту ПТГ на понад } \\
30 \%\end{array}$ & $13(52 \%)$ & $6(40 \%)$ \\
\hline $\begin{array}{l}\text { Зниження вмісту ПТГ на понад } \\
50 \%\end{array}$ & $5(20 \%)$ & $2(13,3 \%)$ \\
\hline Відсоток зниження вмісту ПТГ & $26,26 \%$ & $24,72 \%$ \\
\hline Відсоток зниження вмісту Са & $5,15 \%$ & $2,23 \%$ \\
\hline
\end{tabular}

Патогенез ВГПТ зумовлений багатьма факторами; отже, для зниження рівня ПТГ потрібні різні стратегії лікування. Втім, в клінічній практиці забезпечити задовільний рівень ПТГ у великої частини пацієнтів на діалізі важко, так само як і обмежити ризики, асоційовані з підвищеним вмістом кальцію та фосфору в сироватці крові [6].

Парсабів $є$ новим кальциміметиком тривалої дії, призначеним для внутрішньовенного введення пацієнтам, яким проводять діаліз, тричі на тиждень, на завершення сеансу гемодіалізу.

В масштабних рандомізованих контрольованих досліджень (РКД) застосування етелкальцетиду було ефективнішим за плацебо та не менш ефективним за цинакальцет, за зниженням вмісту ПТГ, без збільшення кількості побічних явищ [3-6, 9].

РКД мають ідеальний дизайн для демонстрації причинно-наслідкового зв'язку між застосуванням специфічних лікарських засобів та забезпечуваною ними користю чи викликаною ними шкодою, в ретельно означених умовах. Проте РКД навіть з бездоганним дизайном не захищені від системної похибки вибірки, зумовленої критеріями включення або не включення пацієнтів до дослідження, а також тим фактом, що втручання призначається пацієнтам лише після їхнього включення в дослідження [6]. Отже, дані, отримані в РКД, можуть бути відірваними від реальної клінічної практики, і не завжди можуть бути повністю перенесені в щоденну практику.
Визнання цінності даних, отриманих в реальній практиці, зростає, оскільки вони забезпечують більш відповідну інформацію щодо ефективності, тоді як дані РКД надають інформацію щодо ефективності нових досліджуваних лікарських препаратів; таким чином, дані, отримані в реальній практиці, доповнюють дані РКД, як дані, отримані в умовах щоденної клінічної практики [6].

В проведеному нами дослідженні продемонстровано, що Парсабів істотно знижує вміст ПТГ у пацієнтів на діалізі в умовах щоденної клінічної практики.

Парсабів виявив більшу ефективність контролю ВГПТ у пацієнтів в порівнянні із застосуванням цинакальцету. В цілому, у 76\% пацієнтів, які отримували Парсабів, тричі на тиждень, на завершенні сеансу гемодіалізу, відбулось зниження вмісту ПТГ в сироватці крові.

Як і очікували, Парсабів знизив вміст кальцію в сироватці крові. Середній вміст загального кальцію залишився в межах діапазону норми у групі Парсабіву та у групі Цинакальцету, хоча зниження рівня загального кальцію і був більшим в групі Парсабіву (2,23\% в порівнянні з 5,15\%), в усіх випадках це не супроводжувалась симптомами гіпокальціємії.

Висновки. Результати проведеного нами обсерваційного дослідження представляють клінічний інтерес. Вони підтверджують, що застосування Парсабіву $€$ новим важливим варіантом лікування пацієнтів з ВГПТ. Парсабів 
виявив більшу ефективність контролю ВГПТ у пацієнтів в порівнянні із застосуванням цинакальцету. Також застосування Парсабіву сприяє зниженню навантаження, спричиненого необхідністю прийому великої кількості лікарських засобів, що $є$ характерним для пацієнтів на ГД, і, таким чином, може сприяти кращому дотриманню рекомендованого терапевтичного режиму, та зрештою, усуненню ризику стійкого ВГПТ. Також $є$ важливим, що Парсабів не взаємодіє 3 ізоферментами системи цитохрому Р450, тобто, відсутні взаємодії з іншими лікарськими засобами, які отримують пацієнти на діалізі [15].

Перспективи. Необхідне проведення подальших досліджень для оцінки клінічних наслідків, а також ефективності та безпеки при довготривалому застосуванні.

\section{ЛITEPATУРA}

1. Дудар I.О., Паламар Б.І., Красюк Е.К., Петрова А.С. Поширеність ХХН VД стадії у світі та в Україні. Здоров'я України. 2015 (3-4): 10-12.

2. Сторожук О.Б., Луговський Е.В., Сторожук Л.О., Сторожук Б.Г., Селезньова І.Б. Вплив вторинного гіперпаратиреозу на деякі показники гемостазу у хворих хронічною хворобою нирок УД стадії. Вісник проблем біології і медицини. 2018. 2 (1): 201-204

3. Block, G.A.; Bushinsky, D.A.; Cunningham, J.; Drueke, T.B.; Ketteler, M.; Kewalramani, R., et al. Effect of Etelcalcetide vs Placebo on Serum Parathyroid Hormone in Patients Receiving Hemodialysis With Secondary Hyperparathyroidism. JAMA. 2017;317(2):146155.

4. Block, G.A.; Bushinsky, D.A.; Cheng, S.; Cunningham, J.; Dehmel, B.; Drueke, T.B., et al. Effect of Etelcalcetide vs Cinacalcet on Serum Parathyroid Hormone in Patients Receiving Hemodialysis. With Secondary Hyperparathyroidism. JAMA 2017; 317(2),156164.

5. David A. Bushinsky, Glenn M. Chertow, Sunfa Cheng, Hongjie Deng, Nelson Kopyt, Kevin J. Martin, et al. One-year safety and efficacy of intravenous etelcalcetide in patients on hemodialysis with secondary hyperparathyroidism. Nephrol Dial Transplant. 2020; 35(10): 17691778

6. Russo D., Tripepi R., Malberti F., lorio D.B., Scognamiglio B., Lullo D.L., et al. Etelcalcetide in Patients on Hemodialysis with Severe Secondary Hyperparathyroidism. Multicenter Studyin "Real Life". J. Clin. Med. 2019, 8(7), 1066;
7. Ketteler $M$, Block GA, Evenepoel $P$, Fukagawa M, Herzog CA, McCann L, et al. Executivesummary of the 2017 KDIGO chronic kidney disease-mineral and bone disorder (CKD-MBD) guideline update: what's changed and why it matters. Kidney Int 2017;92:26-36.

8. Ketteler M, Block GA, Evenepoel P, Fukagawa $M$, Herzog CA, McCann L, et al: Diagnosis, evaluation, prevention, and treatment of chronic kidney disease-mineral and bone disorder: synopsis of the kidney disease: improving global outcomes 2017 clinical practice guideline update. Ann Intern Med 2018; 168: 422430.

9. Martin, K.J.; Pickthorn, K.; Huang, S.; Block, G.A.; Vick, A.; Mount, P.F.; Power, D.A.; Bell, G. AMG 416 (velcalcetide) is a novel peptide for the treatment of secondary hyperparathyroidism in a single-dose study in hemodialysis patients. Kidney Int. 2013, 85 (1): 191-197.

10. Subramanian, R.; Zhu, X.; Kerr, S.J.; Esmay, J.D.; Louie, S.W.; Edson, K.Z.; Walter, S.; Fitzsimmons, M.; Wagner, M.; Soto, M. Nonclinical Pharmacokinetics, Disposition, and Drug-Drug Interaction Potential of a Novel d-Amino Acid Peptide Agonist of the CalciumSensing Receptor AMG 416 (Etelcalcetide). Drug Metab. Dispos. 2016, 44 (8): 1319-1331

\section{PEЗЮME}

\section{КОНТРОЛЬ ВТОРИЧНОГО ГИПЕРПАРАТИРЕОЗА ВНУТРИВЕННЫМ ВВЕДЕНИЕМ ПРЕПАРАТА ПАРСАБИВ У БОЛЬНЫХ ХРОНИЧЕСКОЙ БОЛЕЗНЬЮ ПОЧЕК УД СТАДИИ, НАХОДЯЩИМСЯ НА ГЕМОДИАЛИЗЕ}

Красюк Е.К., Григорьева Е.М., Семерик Ю.П.

$$
\begin{gathered}
\text { Коммунальное неприбыльное предприятие } \\
\text { «Киевский городской центр нефрологии и диализа» } \\
\text { Киев, Украина }
\end{gathered}
$$

Введение. Вторичный гиперпаратиреоз (ВГПТ), частое осложнение хронического заболевания почек, характеризующееся повышенным содержанием паратиреоидного гормона (ПТГ) в сыворотке крови. Парсабив (этекальцетид) является кальцимиметиком для внутривенного введения, который повышает чувствительность кальций-чувствительного рецептора к кальцию и снижает секрецию ПТГ.

Цель. Оценка контроля ВГПТ внутривенным введением Парсабив у больных с терминальной хронической болезнью почек (ХБН), которые лечатся методом гемодиализа (ГД) по сравнению с цинакальцетом для перорального приема.

Материалы и методы. Проведено проспективное обсервационное исследование с включением 40 пациентов с ВГПТ, лечащихся методом ГД, ранее не получавших соответствующего лечения (т.е. никогда ранее не получавших кальцимиметики), пациентов, ранее получавших цинакальцет, а также пациентов, продол- 
жавших получать цинакальцет. Первичным конечным критерием эффективности было количество пациентов со снижением содержания ПТГ более чем на $30 \%$, по сравнению с показателями в начале лечения, на этапе оценки эффективности (недели 12-14) и оценка того, обеспечивает ли Парсабив эффективнее цинакальцета контроль ВГПТ. Вторичные конечные критерии были представлены частью пациентов, достигших в течение периода оценки эффективности снижения концентрации ПТГ более чем на 50\% по сравнению с исходным уровнем и снижения содержания ПТГ и кальция.

Результаты и их обсуждение. В исследование были включены данные 40 пациентов, полученных за период наблюдения продолжительностью 14 недель. Средний возраст 40 пациентов составлял 47,62ะ12,97 года, 70\% были мужчинами. Средняя продолжительность прове-

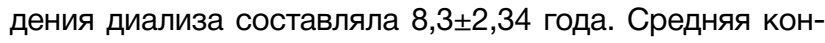
центрация ПТГ до начала исследования и в течение 12-

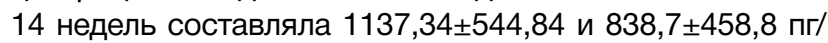

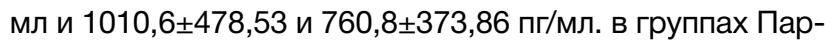
сабива и цинакальцета, соответственно. Среднее содержание общего кальция осталось в пределах диапазона нормы в группе Парсабива и в группе цинакальцета, хотя снижение уровня общего кальция и было выше в группе Парсабива (2,23\% по сравнению с 5,15\%), во всех случаях это не сопровождалось симптомами.

Выводы. Результаты проведённого нами обсервационного исследования представляют клинический интерес. Они подтверждают, что применение Парсабива является новым важным вариантом лечения пациентов с ВГПТ. Парсабив выявил большую эффективность контроля ВГПТ у пациентов по сравнению с применением цинакальцета. В дополнение, применение Парсабива способствует снижению нагрузки, вызванной необходимостью приема большого количества лекарственных средств, характерное для пациентов на диализе, и, таким образом, может способствовать лучшему соблюдению рекомендованного терапевтического режима и устранению риска устойчивого ВГПТ. Также важно, что Парсабив не взаимодействует с изоферментами системы цитохрома Р450, то есть, отсутствуют взаимодействия с другими лекарственными средствами, получаемыми пациентами на диализе.

Необходимо проведение дальнейших исследований для оценки клинических последствий, а также эффективности и безопасности при длительном применении.

Ключевые слова: хроническая болезнь почек, гемодиализ, этелкальцетид, парсабив, цинакальцет, вторичный гиперпаратиреоз.

\section{SUMMARY}

\section{CONTROL OF SECONDARY HYPERPARATIREOSIS BY INTRAVENOUS INTRODUCTION OF PARSABIV IN PATIENTS WITH CHRONIC KIDNEY DISEASE V D STAGE IN HEMODIALYSIS}

\author{
Krasjuk E.K., Grigorieva E.M., Semerik Yu.P. \\ KNP "Kyiv City Center of Nephrology and Dialysis" \\ Kyiv, Ukraine
}

Introduction. Secondary hyperparathyroidism (VGPT), a common complication of chronic kidney disease characterized by elevated serum parathyroid hor- mone (PTH). Parsabiv (etecalcetide) is an intravenous calcimimetic that increases the sensitivity of the calciumsensitive receptor to calcium and reduces the secretion of PTH.

Goal. Evaluation of VGPT control by intravenous administration of Parsabiv in patients with end-stage chronic kidney disease (CKD) treated with hemodialysis (HD) compared with cinacalcet for oral administration.

Materials and methods. A prospective observational study included 40 patients with VGPT treated with HD who had not previously received appropriate treatment (ie, never received calcimimetics before), patients who had previously received cinacalcet, and patients who continued to receive cinacalcet. The primary endpoint for efficacy was the number of patients with a PTH reduction of more than $30 \%$ compared to baseline at the efficacy stage (weeks 12-14) and whether Parsabiv was more effective in controlling VGPT than cinacalcet. Secondary endpoints were presented by some patients who achieved a reduction in PTH levels of more than $50 \%$ from baseline and a reduction in PTH and calcium levels during the evaluation period.

Results and discussion. The study included data from 40 patients obtained during a 14-week follow-up period. The mean age of 40 patients was $47.62 \pm 12.97$ years, $70 \%$ were male. The average duration of dialysis was $8.3 \pm 2.34$ years. The mean PTH concentration before the start of the study and for 12-14 weeks was $1137.34 \pm 544.84$ and $838.7 \pm 458.8 \mathrm{pg} / \mathrm{ml}$ and 1010.6 \pm 478.53 and $760.8 \pm 373.86 \mathrm{pg} / \mathrm{Jr}$. in the Parsabiva and cinacalcet groups, respectively. The mean total calcium remained within the normal range in the Parsabiva group and in the cinacalcet group, although the decrease in total calcium was higher in the Parsabiva group $(2.23 \%$ vs. $5.15 \%$ ), in all cases it was not accompanied by symptoms.

Conclusions. The results of our observational study are of clinical interest. They confirm that the use of Parsabiva is a new important treatment option for patients with VGPT. Parsabiv has been shown to be more effective in controlling VGPT in patients compared with cinacalcet. In addition, the use of Parsabiv helps to reduce the stress caused by the need to take a large number of drugs, typical of dialysis patients, and thus may contribute to better adherence to the recommended treatment regimen and eliminate the risk of persistent VGPT. It is also important that Parsabiv does not interact with isoenzymes of the cytochrome P450 system, that is, there are no interactions with other drugs received by dialysis patients.

Further studies are needed to assess the clinical consequences, as well as efficacy and safety with long-term use.

Key words: chronic kidney disease, hemodialysis, etelcalcetide, parsabiv, cinacalcet, secondary hyperparathyroidism. 


\section{АВТОРСЬКА ДОВІДКА}

\section{Красюк Едуард}

\section{Костянтинович}

КНП «Київський міський центр нефрології та діалізу»,

к.м.Н., директор

Адреса: вулиця Петра Запорожця, 26, Київ, 02125

моб.: 044 540-96-04, +380663888945

E-mail: gem4179@gmail.com

\section{Григор'єва Євгенія}

\section{Михайлівна}

КНП "Київський міський центр нефрології і діалізу"

к.м.Н., заступник директора

Адреса: вулиця Петра Запорожця, 26, Київ, 02125

моб.: 044 540-96-04, +380679419883

E-mail: gem4179@gmail.com

\section{Семерик Ю.П.}

КНП «Київський міський центр

нефрології та діалізу»

лікар

Адреса: вулиця Петра Запорожця, 26,

Київ, 02125

моб.: 044 540-96-04

E-mail: doctor_yelena@ukr.net

\section{Красюк Эдуард \\ Константинович}

КНП «Киевский городской центр нефрологии и диализа», к.м.Н., директор

Адрес: Улица Петра Запорожца, 26, Киев, 02125

моб.: 044 540-96-04, +380663888945

E-mail: gem4179@gmail.com

\section{Григорьева Евгения Михайловна}

КНП "Киевский городской центр нефрологии и диализа" к.м.Н., заместитель директора

Адрес: улица Петра Запорожца, 26, Киев, 02125

моб.: 044 540-96-04, +380679419883

E-mail: gem4179@gmail.com

\section{Семерик Ю.П.}

КНП "Киевский городской центр нефрологии и диализа" врач

Адрес: улица Петра Запорожца, 26 Киев, 02125

моб.: 044 540-96-04

E-mail: doctor_yelena@ukr.net

\section{Krasiuk Eduard}

Kyiv City Center of Nephrology and Dialysis,

Candidate of Medical Sciences,

Director

Address: 26 Petro Zaporozhets Street, Kyiv, 02125

mob.: 044 540-96-04, +380663888945

E-mail: gem4179@gmail.com

\section{Grigorieva Eugenia}

KNP "Kyiv City Center of Nephrology and Dialysis"

PhD, patron of the director

Address: 26 Petro Zaporozhets Street, Kyiv, 02125

mob.: 044 540-96-04, +380679419883

E-mail: gem4179@gmail.com

\section{Semeryk Y.P.}

KNP "Kyiv City Center of Nephrology and Dialysis"

MD

Address: 26 Petro Zaporozhets Street, Kyiv, 02125

mob.: 044 540-96-04

E-mail: doctor_yelena@ukr.net

Стаття надійшла до редакції 03.09.21 p. 